\title{
Environmental disciplines taught to foreign students participating short term exchange programs in RUDN University: experience and approach
}

\author{
Tatyana N. Ledashcheva, Vladimir E. Pinaev ${ }^{\bigotimes}$ \\ Peoples' Friendship University of Russia (RUDN University), \\ 6 Miklukho-Maklaya St, Moscow, 117198, Russian Federation \\ $\bigotimes$ pinaev-ve@rudn.ru
}

\begin{abstract}
The article examines experience and approaches of teaching to foreign students who came to the Institute of Environmental Engineering of the RUDN University for short-term exchange programs (2-3 months). The short duration of the exchange programs imposes additional restrictions on the order of studying the material - it is necessary to give an idea not only about the requirements of environmental protection legislation applied, for example, in Russia and the European Union, but also to give students the opportunity to actively participate in the classes during the workshops, taking into account the adaptation period when in their thoughts they are still at home, but are already in the host country. As an example, the courses conducted at the RUDN for students from Indonesia who arrived to participate the program "Sustainability management" and studying Environmental Impact Assessment and Management of Environmental Risks courses. The experience of teaching these disciplines shows the expediency of practical tasks related to the homeland of students this allows them not only not to miss their homeland, but also to study in more detail the requirements of their country legislation related impact assessment on the environment, but also the impact of various types of industries on the environment. Thus, the students not only does not fall out of the educational context in home country for several months, but also independently receive more in-depth knowledge. As an exam at the end of the course, it is advisable not to give a traditional test with questions, but to prepare a project that can be carried out jointly with colleagues who have remained at the university in their homeland and allows applying the knowledge gained through the exchange program to create a visually evaluated result (project) on environmental protection in their homeland.
\end{abstract}

Keywords: exchange programs, environmental impact assessment, environmental risk management, short term students, adaptation period, RUDN University, project work

Article history: received 30.10.2021; revised 19.11.2021.

For citation: Ledashcheva TN, Pinaev VE. Environmental disciplines taught to foreign students participating short term exchange programs in RUDN University: experience and approach. RUDN Journal of Ecology and Life Safety. 2021;29(2):204-208. http://dx.doi.org/10.22363/23132310-2021-29-2-204-208

(C) Ledashcheva T.N., Pinaev V.E., 2021

(c) () This work is licensed under a Creative Commons Attribution 4.0 International License https://creativecommons.org/licenses/by/4.0/ 


\title{
Обучение экологическим дисциплинам иностранных студентов, приехавших по краткосрочным обменным программам: опыт и подходы РУДН
}

\author{
Т.Н. Ледащева, В.Е. Пинаев ${ }^{\bigotimes}$ \\ Российский университет дружбы народов, \\ Российская Федераџия, 117198, Москва, ул. Миклухо-Маклая, д. 6 \\ 凶inaev-ve@rudn.ru
}

\begin{abstract}
Аннотация. Рассматривается опыт и подходы к обучению иностранных студентов, приехавших на краткосрочные обменные программы (2-3 месяца) в Институт экологии Российского университета дружбы народов. Короткая продолжительность обменных программ накладывает дополнительные ограничения на порядок изучения материала - необходимо дать представление не только о требованиях законодательства по охране окружающей среды, применяемых, например, в России и Европейском союзе, но и предоставить возможность студентам активно участвовать в работе, приняв в расчет период адаптации, когда они еще пребывают в мыслях дома, но уже находятся в стране пребывания. В качестве примера избраны курсы, проводящиеся в РУДН для студентов из Индонезии, прибывших в рамках программы Sustainability Management и обучающихся на курсах Environmental Impact Assessment и Management of Environmental Risks. Опыт преподавания данных дисциплин показывает целесообразность практических заданий, связанных с родиной студентов, - это позволяет им не только не скучать по родине, но и более детально изучить требования законодательства своей страны и воздействие на окружающую среду, а также воздействие различных видов производств на окружающую среду. Таким образом студент не только не выпадает на несколько месяцев из учебного контекста в своей стране, но и самостоятельно получает более углубленные знания. В качестве экзамена по завершении курса представляется целесообразным не традиционный тест с вопросами, а подготовка проекта, который может выполняться совместно с коллегами, оставшимися в университете на родине, и позволяет применить полученные в рамках программы обмена знания для создания визуально оцениваемого результата (проекта) по охране окружающей среды на родине.
\end{abstract}

Ключевые слова: программы обмена, оценка воздействия на окружающую среду, управление экологическим рисками, краткосрочное пребывание, период адаптации, РУДН, проектная работа

История статьи: поступила в редакцию 30.10.2021; принята к публикации 19.11.2021.

Для цитирования: Ledashcheva T.N., Pinaev V.E. Environmental disciplines taught to foreign students participating short term exchange programs in RUDN University: experience and approach // Вестник Российского университета дружбы народов. Серия: Экология и безопасность жизнедеятельности. 2021. Т. 29. № 2. С. 204-208. http://dx.doi.org/10.22363/23132310-2021-29-2-204-208

\section{Introduction}

Short term exchange programs (2-3-month period) for students became more and more popular despite current COVID-19 restrictions. Experience of studying abroad is a precious asset which allows student to have a fresh approach to state of home country, including environmental aspects.

Such programs require grate involvement not only from students but also from professors, in part of environment protection and environmental risk mana- 
gement in theory and practice. Besides knowledge it is necessary to keep proper level of English language among teachers and students, since English language currently is the one which is used for international cooperation.

It is also necessary to take into account approaches already existing in teaching practices - legal requirements [1], international realities, to cover involvement of certain countries in international organizations [2], approaches related to the impact on different components of environment vegetation [3], human society [4], ambient air [5], waste disposal practices [6] and other.

Thus, the main purpose of this report is to demonstrate how short term environmental classes can be done not only interesting but also rewardable for students in the future, since clear that in period of restrictions is easier to create own job, than to get employed by someone.

The research questions raised in the report are the following ones:

RQ1. Can the workshops for environmental disciplines activate students to study hard?

RQ2. Are there big differences to give a test in the end of the course or to defend a project on environment protection or environmental risk decrease?

RQ3. How studying abroad helps student to understand home environment protection legal requirements and practices applied in different industries?

We hypothesize that people when out of the home country still think about it and this can be an additional instrument, that allows students to receive an in depth knowledge of environmental disciplines regarding not only international practices but also regarding practices of environment protection in home country.

\section{Results and discussion}

This report represents the results of studying at short term courses on Environmental Impact Assessment and Management of Environmental Risks. These disciplines are both aimed on assessment and decrease of the impact on the environment. To avoid students participating in both courses it is necessary to form both programs allowing the students to learn something new during both disciplines even environment protection practices can be counted rather limited.

During the classes students need not only to present at the lectures and digest the knowledge presented by the lecturer, but also actively participate in the workshop classes. For this we implement following approach - professor describes and explains local conditions, legal requirements, environment protection and environmental risk assessment practices in Russia and foreign countries, i.e. European Union, and offers the student home task - prepare 10-20 minutes presentation on legal requirements and environment protection practices related to home country, i.e. Indonesia.

So, the students having natural homesick are selecting industries in their home country, which they are interested in and review all available legal requirements and environment protection practices. In the class they are presenting the results orally not only in front of the professor but also all colleagues who are encouraged to ask questions and be involved in each presentation. Such approach allows to form also reasoning and presentation skills.

At the end of the course students are requested to present a case study or a project which they can develop jointly with their colleagues in parent university. 
Such project can not only increase cooperation between the students but also result in a full-scale environmental protection project in home county, what may give them better understanding of environment protection state in home country.

It is also necessary to take into account background of students to make the education process more comfortable for them [7; 8] and rewarding in the future [9], allowing to locate environment protection knowledge among other disciplines.

\section{Conclusion}

At the end of the exchange courses, we expect students be not only familiar with local legislation and practices of environment protection in the country of presence, but also start an environment protection activities or project in a home county. Proposed approach allows to set up interregional cooperation between students, set a project which can result in a business activity in the field of environment protection and receive in depth knowledge of home country environment protection legislation. Such approach also permits to show practical application of environmental disciplines and enable student to find the place in environmental business in future.

\section{References}

[1] Reichert ES. Problems of normative legal regulation training of managers and specialists in the field of environmental protection and environmental safety. Bulletin of the South Ural State University. Ser. Law. 2020;20(1):68-71. (In Russ.) https://doi.org/10.14529/law200110

[2] Galinovskaya E, Otorova B, Ponomarev M. Review of the international scientificpractical conference "Unification and harmonization of environmental legislation within the legal space of the EEU". Journal of Foreign Legislation and Comparative Law. 2017;3(6):108-111. (In Russ.) https://doi.org/10.12737/article_5a1e71dc8891e4.83824238

[3] Solovieva VV, Semenov AA, Yaitsky AS. Environmental education of students by means of hydrobotany. Samara Journal of Science. 2019;8(1):298-303. (In Russ.) http://doi.org/10.24411/2309-4370-2019-11315

[4] Prituzhalova OA, Smolentseva LA, Parusova NS, Serov GP. Environmental protection in the implementation of activities in the environmental sphere as a form of interaction between society and nature, a legal category and the subject of additional professional training. Ekologicheskii Vestnik Rossii. 2018;(9):54-63. (In Russ.)

[5] Jacishin AV, Popov AA, Kovach VE, Artemchuk VA. The methodology of future specialists teaching in ecology using methods and means of environmental monitoring of the atmosphere's surface layer. Informatsionnye Tekhnologii i Sredstva Obucheniya. 2018;66(4):217-230. (In Russ.)

[6] Vasiliev AV. Features of teaching waste management issues in the preparation of bachelors and masters in technical universities. Upravlenie Municipal'nymi Othodami Kak Vazhnyj Faktor Ustojchivogo Razvitija Megapolisa. 2018;(1):281-284. (In Russ.)

[7] Patullaeva ZYu. Basic teaching methods of ecology in higher educational institutions. Mirovaja Nauka. 2020;(12(45)):245-247. (In Russ.)

[8] Vasiliev AV. Experience and problems of teaching university students on environmental programs. Zapad - Rossiya - Vostok. 2018;(12):88-92. (In Russ.)

[9] Khobotova EB. Studying the latest achievements of science in the preparation of bachelor ecologists. Vestnik Khar'kovskogo Natsional'nogo Avtomobil'no-Dorozhnogo Universiteta. 2018;(81):5-11. (In Russ.) 


\section{Список литературы}

[1] Рейхерт E.C. Проблемы нормативного правового регулирования обучения руководителей и специалистов в области охраны окружающей среды и экологической безопасности // Вестник Южно-Уральского государственного университета. Серия: Право. 2020. Т. 20. № 1. С. 68-71. http://doi.org/10.14529/law200110

[2] Галиновская Е.А., Оторова Б.К., Пономарев М.В. Обзор международной научнопрактической конференции «Унификация и гармонизация экологического законодательства в рамках правового пространства ЕАЭС»// Журнал зарубежного законодательства и сравнительного правоведения. 2017. № 6. С. 108-111. https://doi.org/10.12737/article_5a1e71dc8891e4.83824238

[3] Соловьева В.В., Семенов А.А., Яиикий А.С. Экологическое образование студентов средствами гидроботаники // Самарский научный вестник. 2019. Т. 8. № 1. С. 298-303. http://doi.org/10.24411/2309-4370-2019-11315

[4] Притужалова О.А., Смоленцева Л.А., Парусова Н.С., Серов Г.П. Охрана окружающей среды при осуществлении деятельности в экологической сфере как форма взаимодействия общества и природы, правовая категория и предмет дополнительного профессионального обучения // Экологический вестник России. 2018. № 9. C. 54-63.

[5] Яцишин А.В., Попов А.А., Ковач В.Е., Артемчук В.А. Методика обучения будущих специалистов в области экологии методам и средствам экологического мониторинга приземного слоя атмосферы // Информационные технологии и средства обучения. 2018. Т. 66. № 4. С. 217-230.

[6] Васильев A.B. Особенности обучения вопросам обращения с отходами при подготовке бакалавров и магистров в технических вузах // Управление муниципальными отходами как важный фактор устойчивого развития мегаполиса. 2018. № 1. C. 281-284.

[7] Патуллаева 3.У. Основные методы обучения экологии в высших учебных заведениях // Мировая наука. 2020. № 12 (45). С. 245-247.

[8] Васильев A.B. Опыт и проблемы обучения студентов вузов по экологическим программам // Запад - Россия - Восток. 2018. № 12. С. 88-92.

[9] Хоботова Э.Б. Изучение последних достижений науки при подготовке бакалавров-экологов // Вестник Харьковского национального автомобильно-дорожного университета. 2018. № 81. С. 5-11.

\section{Bio notes:}

Tatyana N. Ledashcheva, Cand. Sc. Math., Docent, Department of Environmental Security and Product Quality Management, Institute of Environmental Engineering, Peoples' Friendship University of Russia (RUDN University). E-mail: ledashcheva-tn@rudn.ru

Vladimir E. Pinaev, Cand. Sc. Econ., Docent, Department of Environmental Security and Product Quality Management, Institute of Environmental Engineering, Peoples' Friendship University of Russia (RUDN University). E-mail: pinaev-ve@rudn.ru

\section{Сведения об авторах:}

Ледащева Татьяна Николаевна, кандидат физико-математических наук, доцент, департамент экологической безопасности и менеджмента качества продукции, Институт экологии, Российский университет дружбы народов. E-mail: ledashcheva-tn@rudn.ru

Пинаев Владимир Евгеньевич, кандидат экономических наук, доцент, департамент экологической безопасности и менеджмента качества продукции, Институт экологии, Российский университет дружбы народов. E-mail: pinaev-ve@rudn.ru 